\title{
ANALISIS KESUBURAN PERAIRAN WADUK JATIBARANG BERDASARKAN DISTRIBUSI DAN
} KELIMPAHAN BAKTERI HETEROTROFIK

\author{
Productivity Analysis Jatibarang Reservoir Water Based Distribution and Abundance Heterotrophic Bacteria
}

\section{Siti Nur Hidayah, Niniek Widyorini*), Pujiono Wahyu Purnomo}

Program Studi Manajemen Sumberdaya Perairan, Departemen Sumberdaya Akuatik

Fakultas Perikanan dan Ilmu Kelautan, Universitas Diponegoro

J1. Prof. Soedarto, SH, Tembalang, Semarang, Jawa Tengah - 50275, Telp/Fax. +6224 7474698

Email : hidayah.sitie@yahoo.co.id

\begin{abstract}
ABSTRAK
Waduk Jatibarang terletak di Kecamatan Gunungpati, Kota Semarang. Waduk tersebut digunakan sebagai pengendali banjir, tempat pariwisata, kegiatan menangkap ikan, dan rencana akan dibuat sebagai sumber air bersih melalui PDAM. Pemanfaatan waduk untuk berbagai keperluan kemungkinan dapat menurunkan kualitas air dari waduk tersebut. Penelitian ini mengkaji kesuburan perairan Waduk Jatibarang berdasarkan distribusi dan kelimpahan bakteri heterotrofik. Bakteri heterotrofik berperan penting dalam sistem perairan sebagai perombak dan meremineralisasi bahan-bahan organik menjadi komponen anorganik sederhana. Tujuan dari penelitian ini adalah untuk mengetahui distribusi kelimpahan bakteri heterotrofik, kandungan bahan organik total, hubungan kelimpahan bakteri heterotrofik dengan bahan organik total, dan status kesuburan waduk Jatibarang. Metode yang digunakan dalam penelitian ini adalah metode deskriptif bersifat studi kasus. Sampling dilakukan pada tanggal 27 April dan 11 Mei 2016 di lima (5) stasiun dengan kedalaman 1 meter. Penghitungan kelimpahan bakteri menggunakan metode Total Plate Count (TPC). Pengujian kandungan bahan organik total menggunakan metode Titrimetri Permanganat SNI 06-6989.22-2004. Hasil pengamatan menunjukkan distribusi spasialtemporal bakteri heterotrofik fluktuatif dan relatif tinggi, dengan kelimpahan berkisar $(45-131) \times 10^{5} \mathrm{cfu} / \mathrm{ml}$. Kandungan bahan organik total berkisar 11,771 - 21,883 mg/l. Hubungan antara bakteri heterotrofik dengan bahan organik total yaitu hubungan yang terbalik menunjukkan tidak adanya hubungan antara keduanya. Status kesuburan perairan Waduk Jatibarang berdasarkannilai kelimpahan bakteri heterotrofik $(45-131) \times 10^{5} \mathrm{cfu} / \mathrm{ml}>$ $(22-120) \times 10^{5} \mathrm{cfu} / \mathrm{ml}$ dan kandungan bahan organik total $11,771-21,883 \mathrm{mg} / 1$ perairan bersifat eutrofik.
\end{abstract}

Kata kunci: Waduk Jatibarang; bakteri heterotrofik; bahan organik total; eutrofik

\section{ABSTRACT}

Jatibarang Reservoirs located in District Gunungpati, Semarang. The reservoir are used as flood control, the tourism, fishing activities, and the plan will be created as a source of clean water through the taps. Utilization of reservoirs for various purposes may reduce the quality of the water reservoir. This study examines the productivity waters Jatibarang Reservoir based on the distribution and abundance of heterotrophic bacteria. Heterotrophic bacteria play an important role in aquatic systems as to change and remineralize organic materials into simple inorganic components. The purpose of this study was to determine the distribution of the abundance of heterotrophic bacteria, total organic matter content, abundance of heterotrophic bacteria relationships with total organic matter and productivity status Jatibarang Reservoirs. The method used in this research is descriptive case study. The sampling was conducted on April 27 and May 11, 2016 in five (5) stations with a depth of 1 meter. Calculation of the abundance of bacteria using Total Plate Count (TPC). Tests using a total organic matter content titrimetric method SNI 06-6989.22-2004 permanganate. The results showed the spatial-temporal distribution of heterotrophic bacteria volatile and relatively high, with an abundance range (45-131) x $10^{5} \mathrm{cfu} / \mathrm{ml}$. Total organic matter content ranges (11.771 - 21.883) $\mathrm{mg} / \mathrm{l}$. The relationship between of heterotrophic bacteria with total organic material that is an inverse relationship showed no relationship between both. The productivity status of the dam water Jatibarang based on the abundance of heterotrophic bacteria (45-131) $\times 10^{5} \mathrm{cfu} / \mathrm{ml}>(22-120) \times 10^{5} \mathrm{cfu} / \mathrm{ml}$ and organic matter content of the total $11.771-21.883$ $\mathrm{mg} / \mathrm{l}$ waters are eutrophic.

Keywords: Jatibarang Reservoir; heterotrophic bacteria; total organic matter; eutrophic

*) Penulis Penanggungjawab

${ }^{\circledR}$ Copyright by Management of Aquatic Resources (MAQUARES) 443 


\section{PENDAHULUAN}

Waduk Jatibarang dibangun karena adanya permasalahan banjir yang sering terjadi di Kota Semarang. Waduk Jatibarang selain digunakan sebagai pengendali banjir dari Kali Garang dan beberapa sungai lainnya, Waduk Jatibarang juga digunakan sebagai wisata dan sumber air bersih. Berdasarkan pemanfaatannya, Waduk Jatibarang yang bersifat serbaguna ini perlu dikaji kualitas airnya agar dapat mendukung sebagai obyek wisata. Tujuan memantau kualitas air adalah sebagai sarana pengelolaan sumberdaya yang ada dalam waduk tersebut. Sumberdaya yang ada yaitu terdapat ikan-ikan endemik yang berasal dari aliran sungai-sungai yang masuk ke dalam perairan waduk Jatibarang (Sutomo, 2011 dalam Pramono dan Subowo, 2015).

Berdasarkan informasi yang didapat di Waduk Jatibarang selain terdapat ikan yang berasal dari aliran sungai yang masuk, juga ada yang sengaja menebar benih ikan. Tujuan utama penebaran benih ikan ini adalah untuk meningkatkan produksi sekunder waduk diharapkan dapat meningkatkan aktifitas wisata melalui pemancingan dengan menggunakan perahu dan beberapa alat pancing yang telah tersedia di waduk tersebut. Peningkatan produksi sekunder yang diharapkan dapat berlangsung memerlukan dukungan beberapa komponen akuatik. Salah satu peubah biologi yang mempunyai pengaruh relatif adalah bakteri heterotrofik. Peranannya adalah dalam mendekomposisi bahan organik di waduk untuk menyediakan nutrien.

Waduk Jatibarang merupakan bendungan yang menampung beberapa aliran sungai yang kemudian menjadi sarana prasarana kegiatan akuatik serta mendukung pariwisata yang ada. Kualitas masukan dari lingkungan luar tersebut dari beberapa sungai akan menentukan status kualitas air dan kesuburan di Waduk Jatibarang tersebut. Salah satu indikator penting terkait dengan penentuan kualitas air di perairan tersebut adalah aktivitas bakteri heterotrofik yang dapat mendukung kesediaan unsur hara. Atas hal tersebut maka dilakukan penelitian tentang kesuburan perairan waduk Jatibarang atas berdasarkan kinerja bakteri heterotrofik.

\section{MATERI DAN METODE}

\section{A. MATERI PENELITIAN}

Peralatan yang digunakan dalam penelitian ini antara lain peralatan sampling air, peralatan kultur bakteri, dan peralatan analisis parameter kualitas air. Peralatan yang digunakan untuk pengambilan sampel air terdiri dari botol steril, Vandon Bottle, tabung reaksi steril yang memiliki penutup, label dan kantong plastik. Peralatan yang digunakan dalam kultur bakteri meliputi cawan petri, tabung Erlenmeyer, spreader, pipet, pipet volumetri, tabung reaksi, lampu Bunsen, Hotplate Magnetic Stirer, Autoclave, timbangan elektrik, mikro pipet, inkubator, dan rak tabung. Kemudian peralatan yang digunakan dalam pengukuran parameter fisika kimia antara lain secchi disk, botol BOD, tabung Erlenmeyer, termometer, gelas ukur, pipet ukur, hotplate, dan beaker glass.

Bahan yang digunakan selama penelitian ini antara lain adalah sampel air waduk, tripton, glukosa, yeast, bakto agar, akuades, asam oksalat $0,01 \mathrm{~N}, \mathrm{H}_{2} \mathrm{SO}_{4} 8 \mathrm{~N}$, dan $\mathrm{KMNO}_{4} 0,01 \mathrm{~N}$.

\section{B. METODE PENELITIAN}

Metode yang digunakan dalam penelitian analisis kesuburan perairan yang ditinjau dari distribusi dan kelimpahan bakteri heterotrofik ini adalah metode deskriptif yang bersifat studi kasus. Studi kasus mempelajari objek secara mendalam pada waktu, tempat dan populasi yang terbatas, sehingga memberikan gambaran tentang situasi dan kondisi secara lokal dan hasilnya tidak berlaku untuk tempat dan waktu yang berbeda (Sari et al., 2014 dalam Marwan et al., 2015).

\subsection{Pemilihan Lokasi Sampling}

Pemilihan lokasi pengambilan air sampel dilakukan dengan cara observasi di sekitar Waduk Jatibarang.

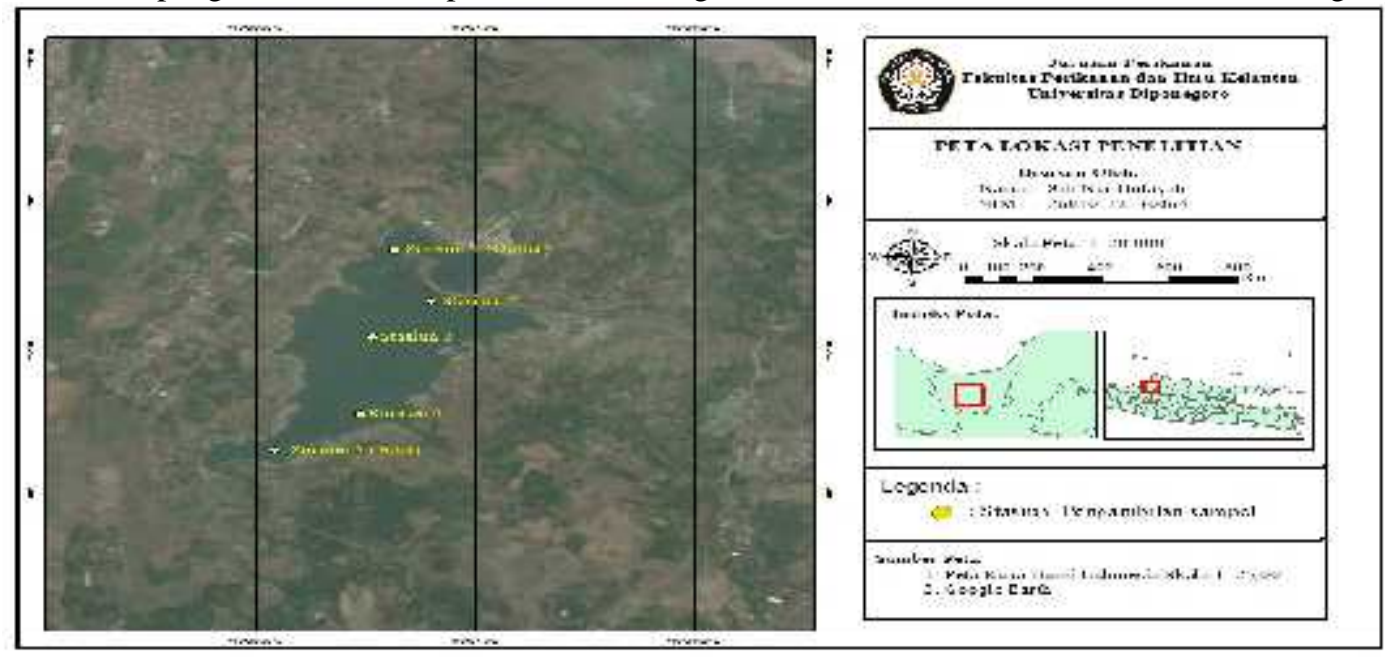

Sumber: Google Earth Digital Globe Data Peta 2016

Gambar 1. Lokasi Stasiun Pengambilan Air Sampel Bakteri Heterotrofik di Waduk Jatibarang, Semarang.

(C) Copyright by Management of Aquatic Resources (MAQUARES) 
Pengambilan air sampel dilakukan pada 5 stasiun, yaitu ; 1) titik outlet terletak pada koordinat 7 2' 10. 51" LS dan 110 20'48. 02" BT, dengan pertimbangan bahwa pada titik ini tidak diperbolehkan adanya aktivitas karena untuk persediaan air bersih dalam mendukung program pembangunan PDAM. 2) Titik Jembatan Kreo terletak pada koordinat 7 2' 22. 09" LS dan 110 20'54. 68" BT, dengan pertimbangan bahwa titik Jembatan Kreo merupakan akses para pengunjung yang berwisata. Hal ini terdapat limbah yang berasal dari aktivitas wisata tersebut. 3) Titik tengah terletak pada koordinat 7 2' 28. 99" LS dan 110 20'45. 97" BT, dengan pertimbangan bahwa daerah ini jauh dari adanya pengaruh aktivitas manusia. 4) Titik inlet sungai Kecebong terletak pada koordinat 7 2' 44. 42" LS dan 110 20'46. 77" BT, dengan pertimbangan bahwa titik ini merupakan lokasi yang digunakan untuk kegiatan pemancingan, sehingga terdapat limbah yang berasal dari kegiatan tersebut. 5) Titik inlet sungai Kreo terletak pada koordinat 7 2' 49.73" LS dan 110 20'34. 32" BT, dengan pertimbangan bahwa titik ini merupakan terjadinya masukan utama dari berbagai limbah yang terbawa dari aliran sungai Kreo yang masuk ke waduk tersebut.

Pengambilan sampel ini dilakukan dengan pengulangan sebanyak dua kali dengan waktu yang berbeda yaitu pada tanggal 27 April dan 11 Mei 2016. Pengambilan air sampel dari masing-masing stasiun telah dilakukan pada kedalaman 1 meter. Menurut Carlson dan Simpson (1996) dalam Juantari et al. (2013), bahwa pola distribusi vertikal populasi bakteri yang tinggi berada pada permukaan hingga kedalaman $50 \mathrm{~m}$. Bertambahnya kedalaman distribusi populasi bakteri makin menurun.

\subsection{Metode Pengambilan Sampel}

Metode sampling yang digunakan adalah menggunakan metode purposive sampling. Menurut Purwanto dan Sulistyastuti (2007) dalam Marwan et al. (2015), purposive sampling adalah pengambilan sampel berdasarkan keperluan penelitian, artinya teknik pengambilan sampel yang dilakukan secara sengajadengan pertimbangan tertentu oleh peneliti. Pengambilan air sampel telah dilakukan dengan menggunakan Vandon bottle untuk mengambil air pada kedalaman $1 \mathrm{~m}$. Air yang sudah didapat kemudian dimasukkan kedalam botol steril yang bervolume $500 \mathrm{ml}$. Botol kemudian ditutup dan dimasukkan ke dalam cool box selama perjalanan. Air sampel yang sudah didapatkan kemudian dibawa ke dalam Laboratorium Pengelolaan Sumberdaya Ikan dan Lingkungan, Universitas Diponegoro Semarang untuk pengujian bakteri dan bahan organik total.

\subsection{Metode Pengukuran Parameter}

Pengukuran parameter pada Waduk Jatibarang dilakukan pada tanggal 27 April 2016 dan 11 Mei 2016 pukul 08.00 WIB. Pengukuran parameter yang dilakukan yaitu meliputi :

a. Kecerahan

Kecerahan diukur pada setiap titik lokasi sampling dengan menggunakan secchi disk. Menurut Effendi (2003) dalam Marwan et al. (2015), persamaan untuk mengukur kecerahan adalah sebagai berikut :

$$
\mathrm{D}=\frac{\mathrm{K} 1+\mathrm{K} 2}{2}
$$

Keterangan :

$\mathrm{D}=$ kecerahan $(\mathrm{cm})$

$\mathrm{K} 1$ = jarak dari permukaan air sampel secchi disk mulai hilang dari pandang $(\mathrm{cm})$

K2 = jarak dari permukaan air sampai secchi disk ditarik ke atas lagi sampai mulai tampak samar $(\mathrm{cm})$

b. Suhu

Pengukuran suhu air menggunakan termometer ke badan perairan.

c. $\mathrm{pH}$

Pengukuran $\mathrm{pH}$ menggunakan $\mathrm{pH}$ paper pada kedalaman 1 meter.

d. Oksigen Terlarut (DO)

Pengukuran oksigen terlarut dengan cara titrasi pada air sampel 1 meter yang dilakukan secara duplo.

\subsection{Metode Analisa Sampel}

\section{Bakteri Heterotrofik}

a. Pembuatan Media Kultur Bakteri

Pembuatan media kultur bakteri heterotrofik yaitu dengan menggunakan media TGY (Tripton Glucost Yeast). Media ini dibuat dengan cara melarutkan bahan tripton 5 gr, glucost 1 gr, extract yeast 2,5 gr, dan bacto agar 15 gr ke dalam aquadest $1000 \mathrm{ml}$.

b. Jumlah Bakteri Heterotrofik

Bakteri yang dihitung merupakan total bakteri heterotrofik yang terdapat di Waduk Jatibarang, Semarang. Penentuan kandungan bakteri menggunakan metode tuang (Pour Plate Method) dengan sampel air sebanyak $500 \mathrm{ml}$ secara aseptis diambil $1 \mathrm{ml}$ dengan menggunakan mikropipet dan dilakukan pengenceran $10^{5}$ dengan aquades steril $9 \mathrm{ml}$ dalam tiap tabung reaksi kemudian diambil 0,1 ml untuk dituangkan kedalam cawan petri steril yang berisi media spesifik yaitu TGY (Tripton Glucost Yeast). Kemudian meratakan dengan menggunakan spreader, lalu menginkubasikan selama $1-2$ hari pada suhu kamar hingga koloni bakteri tumbuh.

C) Copyright by Management of Aquatic Resources (MAQUARES) 
Koloni yang tumbuh dihitung dengan jumlah koloni antara 30 - 300 colony forming unit (cfu). Perhitungan dilakukan dengan cara memberi tanda menggunakan spidol setiap koloni yang dihitung.

Rumus perhitungan jumlah bakteri $(\mathrm{cfu} / \mathrm{ml})$ :

$\mathbf{N}(\mathbf{c f u} / \mathbf{m l})=\mathbf{n}(\mathbf{c f u}) / \mathbf{1 0 0}(\boldsymbol{\mu l}) \times 10^{\mathrm{x}} \times 1000$

Keterangan : $\mathrm{N}=$ Jumlah total bakteri pada sampel uji

$\mathrm{n}$ = Jumlah koloni bakteri pada cawan petri

\section{Bahan Organik Total}

Metode yang digunakan dalam pengukuran bahan organik total berdasarkan SNI 06-6989.22-2004 yaitu pertama memipet $100 \mathrm{ml}$ contoh uji memasukkan ke dalam erlenmeyer $300 \mathrm{ml}$ kemudian dididihkan dengan menggunakan hotplate. Menambahkan $\mathrm{KMnO}_{4} 0,01$ beberapa tetes ke dalam contoh uji hingga terjadi warna merah muda. Menambahkan $5 \mathrm{ml} \mathrm{H}_{2} \mathrm{SO}_{4} 8 \mathrm{~N}$ bebas zat organik. Memanaskan diatas hotplate pada suhu $105 \mathrm{C} \pm$ $2 \mathrm{C}$, bila terdapat bau $\mathrm{H}_{2} \mathrm{~S}$, pendidihan diteruskan beberapa menit. Memipet $10 \mathrm{~mL}$ larutan baku $\mathrm{KMnO}_{4} 0,01 \mathrm{~N}$. Memanaskan hingga mendidih selama 10 menit. Memipet $10 \mathrm{~mL}$ larutan baku asam oksalat 0,01 N. Kemudian menitrasi dengan $\mathrm{KMnO}_{4}$ 0,01 N hingga warna merah muda. Kemudian mencatat volume pemakaian $\mathrm{KMnO}_{4}$, apabila pemakaian larutan baku $\mathrm{KMnO}_{4}$ 0,01 N lebih dari $7 \mathrm{~mL}$, mengulangi pengujian dengan cara mengencerkan contoh uji.

Mencari nilai bahan organik total yaitu dengan memasukkan hasil pencatatan kedalam rumus perhitungan sebagai berikut :

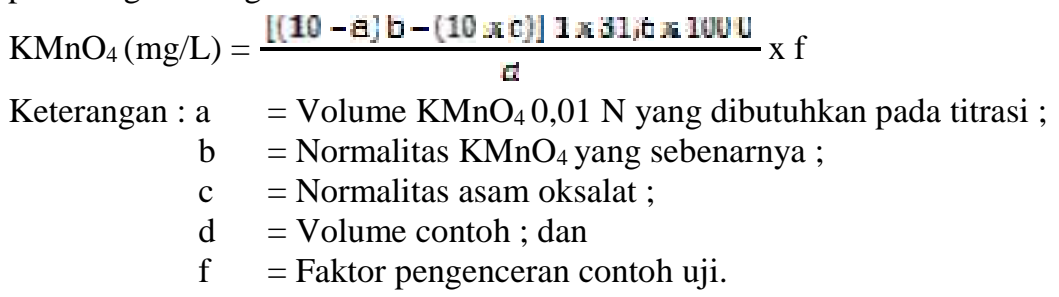

\subsection{Analisis Data}

Analisis data yang digunakan dalam penelitian ini yaitu uji statistik parametrik. Uji statistik parametrik harus memenuhi syarat penggunaannya yaitu ragam data homogen dan data menyebar menurut kurva normal. Data yang sudah homogen dan normal maka dianalisis regresi untuk mencari hubungan total bakteri heterotrofik dengan bahan organik total berdasarkan nilai korelasinya. Penelitan ini terdapat hipotesis sebagai berikut :

- $\mathrm{H}_{0}$ : tidak terdapat hubungan antara jumlah bakteri heterotrofik dengan bahan organik total.

- $\mathrm{H}_{1}$ : terdapat hubungan antara jumlah bakteri heterotrofik dengan bahan organik total.

Dasar pengambilan keputusan berdasarkan probabilitas adalah :

- Jika probabilitas $>0,05$, maka $\mathrm{H}_{0}$ diterima

- Jika probabilitas <0,05, maka $\mathrm{H}_{0}$ ditolak

Menurut Sarwono (2006) dalam Sarwono (2016), bahwa koefisien korelasi ialah pengukuran statistik kovarian atau asosiasi antara dua variabel. Besarnya koefisien korelasi berkisar antara +1 s/d -1 . Koefisien korelasi menunjukkan kekuatan (strenghth) hubungan linear dan arah hubungan dua variabel acak. Koefisien korelasi negatif maka kedua variabel mempunyai hubungan searah. Hubungan searah yaitu artinya jika nilai variabel $\mathrm{X}$ tinggi, maka nilai variabel $\mathrm{Y}$ akan tinggi pula. Koefisien korelasi negatif, maka kedua variabel mempunyai hubungan terbalik. Hubungan terbalik yaitu artinya jika nilai variabel $\mathrm{X}$ tinggi, maka nilai variabel Y akan menjadi rendah dan berlaku sebaliknya.

Menurut Sugiyono (2007) dalam Marwan et al. (2015), untuk mengetahui korelasi antara dua variabel maka diperlukan pengujian (r) dengan kriteria sebagai berikut :

$\mathrm{r}=0 \quad$ : tidak memiliki korelasi

$0<\mathrm{r} \leq 0,19$ : korelasi sangat rendah (lemah sekali)

$0,2<\mathrm{r} \leq 0,39$ : korelasi rendah (lemah tapi pasti)

$0,4<\mathrm{r} \leq 0,69$ : korelasi cukup

$0,7<\mathrm{r} \leq 0,89$ : korelasi tinggi

$0,9<\mathrm{r} \leq 1 \quad$ : korelasi sangat tinggi dan kuat

$\mathrm{r}=1 \quad$ : korelasi sempurna 


\section{HASIL DAN PEMBAHASAN}

\section{Hasil}

\section{a. Deskripsi Lokasi}

Lokasi pengambilan sampel air terletak pada Waduk Jatibarang yang merupakan wilayah Desa Kandri, Kecamatan Gunungpati, Kota Semarang. Waduk Jatibarang adalah waduk satu-satunya yang ada di Kota Semarang. Waduk Jatibarang yang merupakan salah satu pintu masuk menuju Goa Kreo mulai dibangun pada tahun 2009 dan diresmikan bertepatan dengan peringatan Hari Air Dunia pada 5 Mei 2014. Secara teknis, waduk Jatibarang memiliki kapasitas 20,4 juta $\mathrm{m}^{3}$ dengan volume air itu maka akan mampu menjadi sumber air baku dengan kapasitas $1.050 \mathrm{~m}^{3} / \mathrm{s}$, dan pembangkit listrik mikro hidro dengan kapasitas 1,5 megawatt. Badan tubuh bendungan berupa urugan batu berzona dengan inti di tengah, daerah tangkapan $54 \mathrm{~km}^{2}$, luas genangan 184 ha, muka air maksimum $\pm 155,30$, tinggi di atas pondasi $74 \mathrm{~m}$, elevasi puncak $\pm 157 \mathrm{~m}$, panjang puncak $200 \mathrm{~m}$. Pembuatan sistem pengambilan (intake) dengan tipe pengambilan miring sistem pengambilan menggunakan struktur pipa baja yang ditanam 1,4 di dasar terowongan. Waduk ini luasnya sekitar 46,56 hektar yang berfungsi sebagai pengendali banjir di Kota Semarang, pembangkit listrik, dan sarana irigasi.

\section{b. Distribusi - Kelimpahan Bakteri Heterotrofik}

Berdasarkan perhitungan populasi bakteri heterotrofik di Waduk Jatibarang diperoleh hasil yang dapat dilihat pada tabel 1. dibawah ini, yaitu :

Tabel 1. Hasil Distribusi - Kelimpahan Bakteri Heterotrofik x $10^{4}$ (cfu/ml) di Waduk Jatibarang

\begin{tabular}{ccc}
\hline Total Bakteri & Sampling I (27 April 2016) & Sampling II (11 Mei 2016) \\
\hline Stasiun 1 & 550 & 700 \\
Stasiun 2 & 1070 & 1040 \\
Stasiun 3 & 1200 & 540 \\
Stasiun 4 & 1310 & 450 \\
Stasiun 5 & 810 & 900
\end{tabular}

Keterangan : Stasiun 1 = Outlet, Stasiun 2 = Jembatan Kreo, Stasiun $3=$ Tengah, Stasiun $4=$ Inlet Sungai Kecebong, Stasiun 5 = Inlet Sungai Kreo.

Hasil perhitungan total bakteri ini dapat disajikan kedalam diagram batang distribusi dan kelimpahan bakteri heterotrofik di lima (5) stasiun, dapat dilihat pada gambar 2. di bawah ini :

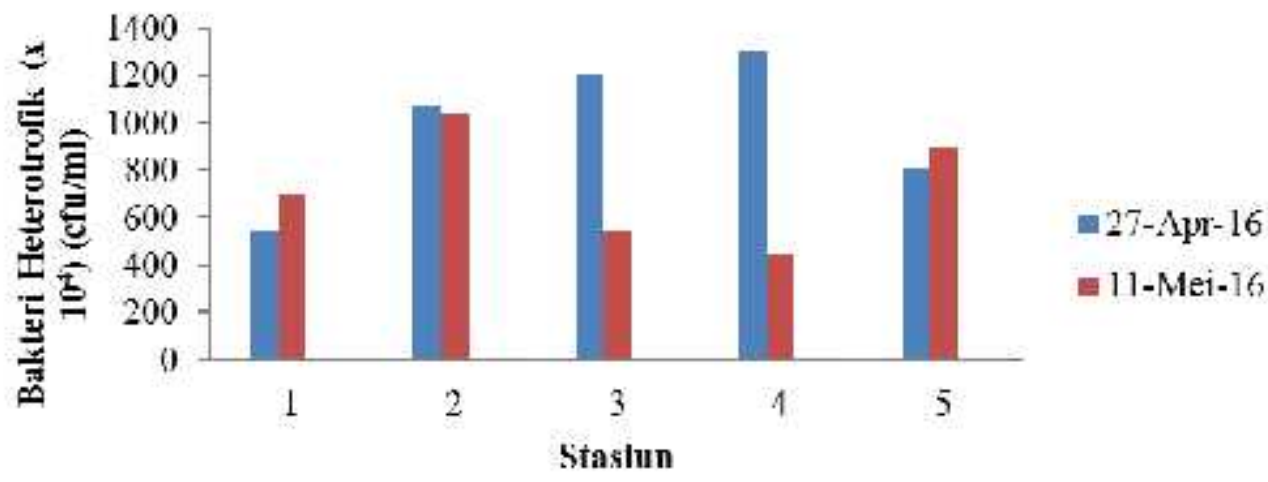

Gambar 2. Distribusi dan Kelimpahan Bakteri Heterotrofik

Gambar 2. bahwa distribusi dan kelimpahan bakteri heterotrofik di lima stasiun dengan selang waktu yang berbeda yaitu pada tanggal 27 April dan 11 Mei 2016. Kelimpahan bakteri heterotrofik pada sampling pertama yang tertinggi yaitu pada stasiun inlet sungai Kecebong sebesar $1310 \times 10^{4} \mathrm{cfu} / \mathrm{mL}$ dan yang terendah terdapat pada stasiun Outlet sebesar $550 \times 10^{4} \mathrm{cfu} / \mathrm{ml}$. Kelimpahan bakteri heterotrofik pada sampling kedua yang tertinggi yaitu pada stasiun jembatan Kreo sebesar $1040 \times 10^{4} \mathrm{cfu} / \mathrm{ml}$ dan yang terendah terdapat pada stasiun Inlet Sungai Kecebong sebesar 450 x $10^{4} \mathrm{cfu} / \mathrm{ml}$. 


\section{b. Bahan Organik Total}

Berdasarkan pengujian kandungan bahan organik total (mg/l) di Waduk Jatibarang diperoleh hasil yang dapat dilihat pada tabel 2. dibawah ini, yaitu :

Tabel 2. Hasil Bahan Organik Total (mg/l) pada Perairan Waduk Jatibarang

\begin{tabular}{ccc}
\hline Bahan Organik Total & Sampling I (27 April 2016) & Sampling II (11 Mei 2016) \\
\hline Stasiun 1 & 14,694 & 14,852 \\
Stasiun 2 & 11,771 & 13,193 \\
Stasiun 3 & 14,299 & 15,563 \\
Stasiun 4 & 15,326 & 16,748 \\
Stasiun 5 & 21,883 & 19,276 \\
\hline
\end{tabular}

Keterangan : Stasiun 1 = Outlet, Stasiun 2 = Jembatan Kreo, Stasiun 3 = Tengah, Stasiun $4=$ Inlet Sungai Kecebong, Stasiun 5 = Inlet Sungai Kreo.

Hasil pengujian kandungan bahan organik total di lima (5) stasiun ini dapat disajikan dalam diagram batang yang dapat dilihat di bawah ini, yaitu :

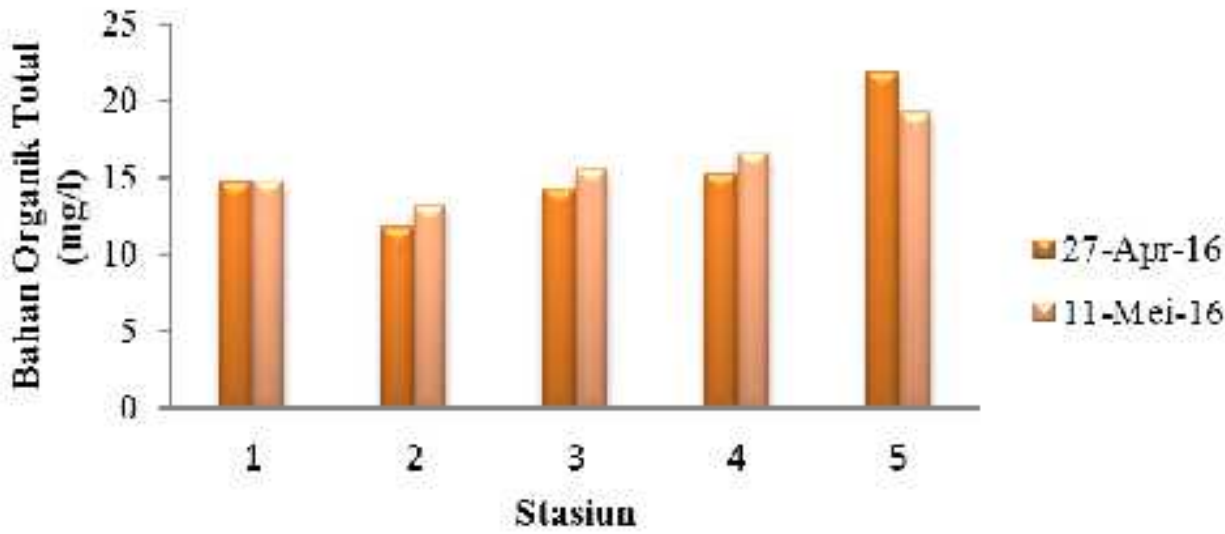

Gambar 3. Kandungan Bahan Organik Total (mg/l)

Gambar 3. bahwa kandungan bahan organik total di lima stasiun dengan selang waktu yang berbeda yaitu pada tanggal 27 April dan 11 Mei 2016. Kandungan bahan organik total pada sampling pertama yang tertinggi yaitu pada stasiun Inlet Sungai Kreo sebesar $21,883 \mathrm{mg} / \mathrm{l}$ dan yang terendah terdapat pada stasiun Jembatan Kreo sebesar 11,771 mg/l. Kandungan bahan organik total pada sampling kedua yang tertinggi yaitu pada stasiun Inlet Sungai Kreo sebesar 19,276 mg/L dan yang terendah terdapat pada stasiun Jembatan Kreo sebesar 13,193 mg/l.

\section{c. Hubungan Bakteri Heterotrofik dengan Bahan Organik Total}

Berdasarkan perhitungan total bakteri heterotrofik $(\mathrm{cfu} / \mathrm{ml})$ dan pengujian kandungan bahan organik total (mg/l) telah diperoleh persamaan regresi linier pada Gambar 5. dibawah ini, yaitu :

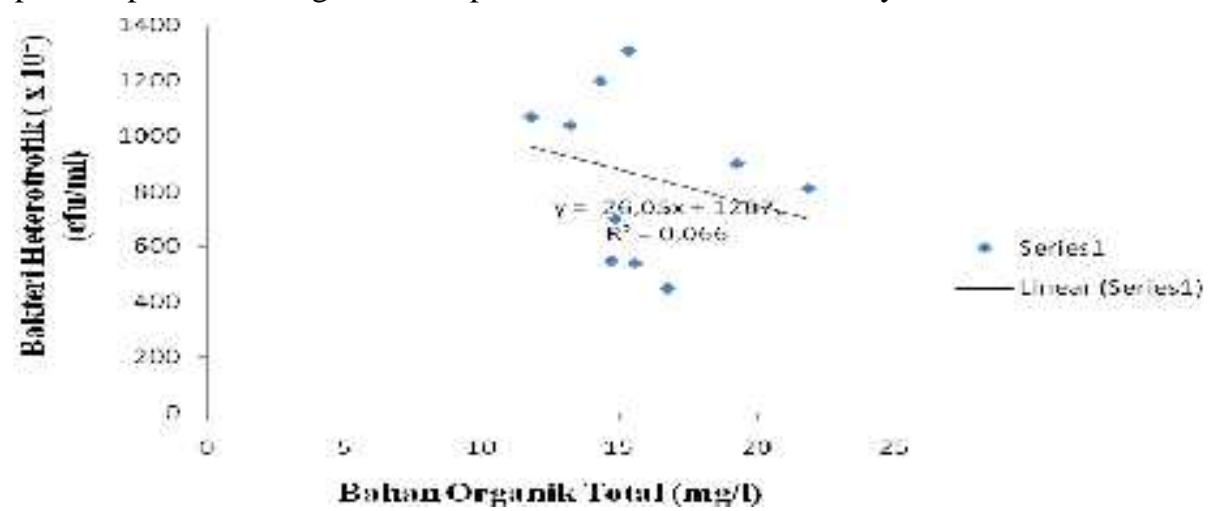

Gambar 4. Hubungan Total Bakteri Heterotrofik (cfu/ml) dengan Bahan Organik Total (mg/l)

\footnotetext{
${ }^{\text {C) }}$ Copyright by Management of Aquatic Resources (MAQUARES)
} 
Gambar 4. di atas menunjukkan adanya hubungan yang terbalik antara total bakteri heterotrofik dengan kandungan bahan organik total, disamping itu hasil uji (lampiran 8.) menunjukkan bahwa tidak memperlihatkan adanya hubungan antara bakteri heterotrofik dengan bahan organik total.

\section{d. Kualitas Perairan} berikut :

Parameter kualitas perairan yang diukur antara lain suhu air, kecerahan, pH, DO pada tabel 3. sebagai Tabel 3. Hasil Pengukuran Parameter Kualitas Perairan Waduk Jatibarang Pukul 08.00 WIB

\begin{tabular}{|c|c|c|c|c|c|}
\hline \multirow{2}{*}{ Stasiun } & \multirow{2}{*}{ Sampling } & \multicolumn{4}{|c|}{ Parameter } \\
\hline & & Suhu ( C) & Kecerahan $(\mathrm{cm})$ & $\mathrm{pH}$ & $\mathrm{DO}(\mathrm{mg} / \mathrm{l})$ \\
\hline \multirow[t]{2}{*}{1} & I & 29 & 115 & 6 & 4,2 \\
\hline & II & 30 & 115 & 6 & 4 \\
\hline \multirow[t]{2}{*}{2} & I & 29 & 110 & 6 & 8,12 \\
\hline & II & 30 & 110 & 6 & 8,24 \\
\hline \multirow[t]{2}{*}{3} & I & 30 & 140 & 6 & 8 \\
\hline & II & 30 & 142,5 & 6 & 8,20 \\
\hline \multirow[t]{2}{*}{4} & I & 30 & 145 & 6 & 8 \\
\hline & II & 30 & 145 & 6 & 8,24 \\
\hline \multirow[t]{2}{*}{5} & I & 30 & 120 & 6 & 8 \\
\hline & II & 30,5 & 120 & 6 & 8 \\
\hline \multicolumn{2}{|c|}{ Pustaka } & $\left.25-37^{a}\right)$ & $\begin{array}{c}\leq 2,5 \mathrm{~m} \\
\text { (Hipereutrof) }^{\mathrm{b})}\end{array}$ & $6-8^{c)}$ & $\geq 3 \mathrm{mg} / \mathrm{l}^{\mathrm{d})}$ \\
\hline
\end{tabular}

Sumber : (Penelitian, 2016).

Keterangan :

a) Kristiawan et al., 2014

b) Sayekti et al., 2015

c) Kristiawan et al., 2014

d) Effendi et al., 2012

Tabel 3. Menunjukkan hasil yang diperoleh dari pengukuran parameter kualitas air di Waduk Jatibarang. Nilai suhu air berkisar antara 29 - 30,5 (C). Nilai kecerahan berkisar antara 110 - $145(\mathrm{~cm})$. Nilai pH yang diperoleh yaitu sebesar 6. Nilai DO (Dissolved Oxygen) berkisar antara $4-8,24$ (mg/l).

\section{Pembahasan}

\section{a. Distribusi dan Kelimpahan Bakteri Heterotrofik}

Berdasarkan hasil distribusi dan kelimpahan bakteri heterotrofik menunjukkan fluktuasi dan relatif tinggi. Kelimpahan bakteri heterotrofik pada sampling pertama (27 April 2016) menunjukkan kisaran antara (550 1310) $\times 10^{4} \mathrm{cfu} / \mathrm{ml}$ dengan rata-rata jumlahnya $988 \times 10^{4} \mathrm{cfu} / \mathrm{ml}$. Kelimpahan bakteri heterotrofik paling tinggi ditemukan pada stasiun 4 (inlet Sungai Kecebong) yaitu $1310 \times 10^{4} \mathrm{cfu} / \mathrm{ml}$, dan terendah di stasiun 1 (outlet) yaitu $550 \times 10^{4} \mathrm{cfu} / \mathrm{ml}$. Beberapa stasiun lain yang memiliki kelimpahan bakteri heterotrofik yang cukup tinggi yaitu 2, 3, dan 5. Stasiun 2 (Jembatan Kreo) memiliki kelimpahan bakteri heterotrofik sebesar 1070 x $10^{4} \mathrm{cfu} / \mathrm{ml}$. Stasiun 3 (tengah) memiliki kelimpahan bakteri heterotrofik sebesar $1200 \times 10^{4} \mathrm{cfu} / \mathrm{ml}$. Stasiun 5 (inlet Sungai Kreo) memiliki kelimpahan bakteri heterotrofik sebesar 810 × $10^{4} \mathrm{cfu} / \mathrm{ml}$.

Tingginya kelimpahan bakteri heterotrofik pada stasiun penelitian diindikasikan terkait adanya pengaruh limbah rumah tangga terbawa aliran Sungai Garang yang masuk ke dalam perairan waduk. Masuknya sumber limbah tersebut telah mempengaruhi pertumbuhan bakteri heterotrofik. Berdasarkan hal tersebut dalam penelitian yang telah dilakukan pada beberapa stasiun ditemukan kelimpahan bakteri heterotrofik tertinggi pada stasiun 4 (inlet Sungai Kecebong) memiliki kelimpahan bakteri heterotrofik 1310 x $10^{4} \mathrm{cfu} / \mathrm{ml}$. Stasiun ini merupakan tempat yang paling ramai digunakan untuk lokasi pemancingan dan terdapat genangan sampah yang menumpuk berupa botol-botol mineral, dan limbah dari umpan yang digunakan pada kegiatan pemancingan tersebut, diduga dapat mempengaruhi pertumbuhan bakteri heterotrofik yang ada dalam perairan tersebut. Kelimpahan bakteri heterotrofik terendah ditemukan pada stasiun 1 (outlet). Stasiun 1 (outlet) merupakan wilayah yang tidak boleh dilakukan aktivitas apapun, karena akan digunakan untuk pelaksanaan program pembangunan PDAM. Program ini akan berfungsi untuk menyediakan sumber air bersih untuk penduduk.

Kelimpahan bakteri heterotrofik pada sampling kedua (11 Mei 2016) menunjukkan kisaran antara (450 1040) $\times 10^{4} \mathrm{cfu} / \mathrm{ml}$ dengan rata-rata jumlahnya $726 \times 10^{4} \mathrm{cfu} / \mathrm{ml}$. Kelimpahan bakteri heterotrofik paling tinggi ditemukan pada stasiun 2 (Jembatan Kreo) yaitu 1040 × $10^{4} \mathrm{cfu} / \mathrm{ml}$, dan terendah di stasiun 4 (inlet Sungai Kecebong). Beberapa stasiun lain yang memiliki kelimpahan bakteri heterotrofik yang cukup tinggi yaitu 1, 3, dan 5. Stasiun 1 (outlet) memiliki kelimpahan bakteri heterotrofik sebesar $700 \times 10^{4} \mathrm{cfu} / \mathrm{ml}$. Stasiun 3 (tengah) 
memiliki kelimpahan bakteri heterotrofik sebesar 540 x $10^{4} \mathrm{cfu} / \mathrm{ml}$. Stasiun 5 (inlet Sungai Kreo) memiliki kelimpahan bakteri heterotrofik sebesar $900 \times 10^{4} \mathrm{cfu} / \mathrm{ml}$.

Berdasarkan rata-rata kelimpahan bakteri heterotrofik pada sampling kedua menunjukkan hasil yang lebih rendah dibanding dengan sampling pertama. Hal ini disebabkan selama selang dua minggu tersebut turun hujan, yang diduga dapat mengakibatkan penurunan jumlah kelimpahan bakteri heterotrofik yang ada di beberapa stasiun, yaitu stasiun 2, 3, dan 4. Penurunan jumlah kelimpahan bakteri heterotrofik yang berbeda jauh terdapat pada stasiun 3 (tengah) dan stasiun 4 (inlet Sungai kecebong). Kelimpahan bakteri heterotrofik di stasiun 3 (tengah) pada sampling pertama yaitu $1200 \times 10^{4} \mathrm{cfu} / \mathrm{ml}$, sedangkan pada sampling kedua $540 \times 10^{4} \mathrm{cfu} / \mathrm{ml}$. Kelimpahan bakteri heterotrofik di stasiun 4 (inlet Sungai Kecebong) pada sampling pertama 1310 × $10^{4} \mathrm{cfu} / \mathrm{ml}$, sedangkan pada sampling kedua $450 \times 10^{4} \mathrm{cfu} / \mathrm{ml}$. Hal ini menunjukkan bahwa pada sampling pertama kondisi perairan waduk Jatibarang terjadi aktivitas perombakan organik yang lebih tinggi. Menurut Rheinheimer (1995) dalam Badjoeri dan Lukman (2010), bahwa bakteri heterotrofik di perairan akan memanfaatkan bahan organik sebagai sumber karbon untuk energi metabolisme dan pertumbuhannya.

\section{b. Bahan Organik Total}

Hasil kandungan bahan organik total pada sampling pertama menunjukkan kisaran antara $(11,771-21,883)$ $\mathrm{mg} / \mathrm{l}$, dengan rata-rata kandungannya $15,594 \mathrm{mg} / \mathrm{l}$. Kandungan bahan organik total paling tinggi ditemukan pada stasiun 5 (inlet Sungai Kreo) yaitu 21,883 mg/l, dan terendah pada stasiun 2 (Jembatan Kreo) yaitu 11,771 mg/l. Beberapa stasiun lain yang memiliki kandungan bahan organik total yang cukup tinggi adalah 1, 3 , dan 4 . Stasiun 1 (outlet) memiliki kandungan bahan organik total sebesar 14,694 mg/l. Stasiun 3 (tengah) memiliki kandungan bahan organik total sebesar 14,299 mg/l. Stasiun 4 (inlet Sungai Kecebong) memiliki kandungan bahan organik total sebesar $15,326 \mathrm{mg} / \mathrm{l}$.

Pada stasiun 5 (inlet Sungai Kreo) yang merupakan aliran Sungai Garang yang masuk ke perairan Waduk Jatibarang adalah inlet utama, kandungan bahan organik total yang didapatkan dari stasiun 5 adalah yang paling tinggi, hal ini diduga karena aktivitas manusia yang menghasilkan limbah rumah tangga baik organik maupun anorganik yang berasal dari aliran Sungai Garang. Pada stasiun 1 (outlet) kandungan bahan organik total juga cukup tinggi $(14,694 \mathrm{mg} / \mathrm{l})$, stasiun ini merupakan wilayah yang tidak boleh dilakukan aktivitas apapun, karena stasiun ini akan digunakan untuk pelaksanaan program pembangunan PDAM. Program ini akan berfungsi untuk menyediakan sumber air bersih untuk penduduk, sehingga wilayah ini merupakan wilayah terkendali. Kandungan bahan organik total yang ditemukan pada stasiun ini cukup tinggi karena mendapatkan sinar matahari yang cukup. Stasiun 3 (tengah) merupakan wilayah yang sering dilalui oleh perahu wisata. Stasiun 4 (inlet Sungai Kecebong), merupakan lokasi pemancingan yang paling ramai dan terdapat genangan sampah yang menumpuk. Sampah berupa botol-botol dan bungkus makanan yang berasal dari limbah para pengunjung yang memancing di Waduk Jatibarang. Kandungan bahan organik total yang terendah ditemukan pada stasiun 2 (Jembatan Kreo) yaitu sebesar 11,771 mg/l. Stasiun 2 (Jembatan Kreo) merupakan yang diduga dipengaruhi aktivitas para pengunjung wisata Goa Kreo yang sering memberikan makanan pada satwa-satwa yang berada di bawah Jembatan Kreo. Makanan tersebut dapat terbuang ke perairan Waduk Jatibarang. Hal ini selain limbah organik juga limbah anorganik (botol-botol mineral, plastik, dan lain-lain) yang terbuang ke perairan tersebut.

Kandungan bahan organik total pada sampling kedua (11 Mei 2016) menunjukkan kisaran antara (13,193 $19,276) \mathrm{mg} / \mathrm{l}$ dengan rata-rata jumlahnya 15,926 . Kandungan bahan organik total paling tinggi ditemukan pada stasiun 5 (inlet Sungai Kreo) yaitu 19,276 mg/l, dan terendah di stasiun 2 (Jembatan Kreo) yaitu 13,193 mg/l. Beberapa stasiun lain yang memiliki kandungan bahan organik total yang cukup tinggi yaitu 1, 3, dan 4. Stasiun 1 (outlet) memiliki kandungan bahan organik total sebesar 14,852 mg/l. Stasiun 3 (tengah) memiliki kandungan bahan organik total sebesar 15,563 mg/l. Sungai Stasiun 4 (inlet Sungai Kecebong) memiliki kandungan bahan organik total sebesar $16,748 \mathrm{mg} / \mathrm{l}$.

Berdasarkan rata-rata kandungan bahan organik total pada sampling kedua menunjukkan hasil yang lebih tinggi dibanding dengan sampling pertama. Hasil kandungan bahan organik total pada stasiun 5 (inlet Sungai Kecebong) mengalami penurunan pada sampling kedua yaitu 21, $883 \mathrm{mg} / \mathrm{l}$ sedangkan pada sampling pertama yaitu 19,276 mg/l. Menurut Sulawesty et al. (2013), tingginya kandungan bahan organik total di waduk ini adalah masukan dari daerah sekelilingnya, ini ada hubungannya dengan fungsi waduk sebagai tempat menampung air sehingga air permukaan dari sekeliling waduk akan masuk ke waduk dengan membawa materi organik yang ada.

\section{c. Hubungan Bakteri Heterotrofik dengan Bahan Organik Total}

Berdasarkan hasil uji statistik yang telah dilakukan untuk memperoleh korelasi antara total bakteri heterotrofik dan bahan organik total didapatkan nilai r sebesar 0,258. Nilai korelasi ini menurut Sugiyono (2007) dalam Marwan et al. (2015), menunjukkan tidak adanya hubungan antara bakteri heterotrofik dengan bahan organik total. Hal ini disebabkan kelimpahan bakteri heterotrofik dan kandungan bahan organik total yang sudah tinggi di perairan. Kelimpahan bakteri heterotrofik yang didapatkan yaitu $(45-131) \times 10^{4} \mathrm{cfu} / \mathrm{ml}$ dan kandungan bahan organik total $(11,771$ - 21,883) $\mathrm{mg} / \mathrm{l}$. Kondisi perairan waduk Jatibarang dengan kelimpahan bakteri heterotrofik dan kandungan bahan organik total yang tinggi menunjukkan perairan tersebut bersifat eutrofik. Menurut Rheinheimer (1985) dalam Badjoeri (2013), kelimpahan bakteri heterotrofik apabila di waduk telah

${ }^{\circledR}$ Copyright by Management of Aquatic Resources (MAQUARES) 
mencapai jumlah yang dapat digolongkan yaitu $50-340 \times 10^{3}$ cfu/mL (oligotrofik), $4-14 \times 10^{5} \mathrm{cfu} / \mathrm{mL}$ (mesotrofik), dan $22-120 \times 10^{5}$ (eutrofik).

Keterkaitan antara kelimpahan bakteri heterotrofik dengan kandungan bahan organik total dalam penelitian ini ialah dapat dibuktikan berdasarkan hasil yang telah didapatkan, yaitu kelimpahan bakteri heterotrofik tertinggi terdapat di stasiun 4 (inlet sungai Kecebong) pada sampling pertama dan di stasiun 2 (jembatan Kreo) pada sampling kedua. Rata-rata kelimpahan bakteri heterotrofik pada kedua waktu sampling menunjukkan hasil yang lebih tinggi pada sampling pertama. Hal ini disebabkan pada sampling pertama terjadi aktivitas perombakan organik oleh bakteri heterotrofik yang lebih tinggi dibanding pada sampling kedua. Kandungan bahan organik total tertinggi terdapat di stasiun 5 (inlet sungai Kreo) dan juga pada sampling kedua. Kelimpahan bakteri heterotrofik tertinggi adalah $1310 \times 10^{4} \mathrm{cfu} / \mathrm{ml}$ dan kandungan bahan organik total tertinggi adalah 21,883 mg/l dengan kisaran suhu antara 29 - 30,5 C. Menurut Hayes (2000), mengemukakan bahwa kelimpahan bakteri sering terjadi pada lingkungan perairan yang kaya bahan organik dengan suhu lebih dari 10 C. Menurut Widiyanto (2006) dalam Badjoeri dan Widiyanto (2008), tingginya akumulasi bahan organik di perairan dapat menimbulkan beberapa dampak yang merugikan yaitu, 1) memacu pertumbuhan mikroorganisme heterotrofik dan bakteri patogen, 2) eutrofikasi, 3) terbentuknya senyawa toksik (amonia dan nitrit), dan 4) menurunnya konsentrasi oksigen terlarut.

\section{d. Status Kesuburan Waduk Jatibarang}

Status kesuburan perairan Waduk Jatibarang berdasarkan kandungan bahan organik total, bakteri heterotrofik dan oksigen terlarut (DO). Kandungan bahan organik total yang didapatkan yaitu pada kisaran antara $(11,771-21,883) \mathrm{mg} / \mathrm{l}$. Kondisi perairan waduk yang tergenang memberikan peluang bahan organik total untuk mengendap, sehingga pada dasar waduk akan terjadi akumulasi bahan organik yang cukup tinggi.

Kelimpahan bakteri heterotrofik yang didapatkan yaitu pada kisaran antara $450-1310 \times 10^{4} \mathrm{cfu} / \mathrm{ml}$ adalah $45-131 \times 10^{5} \mathrm{cfu} / \mathrm{ml}$. Hal ini menunjukkan kelimpahan bakteri heterotrofik yang tinggi dan dikategorikan kedalam perairan yang subur (eutrofik). Menurut Rheinheimer (1985) dalam Badjoeri (2013), kelimpahan bakteri heterotrofik apabila di waduk telah mencapai jumlah yang dapat digolongkan yaitu $50-340 \times 10^{3} \mathrm{cfu} / \mathrm{ml}$ (oligotrofik), $4-14 \times 10^{5} \mathrm{cfu} / \mathrm{ml}$ (mesotrofik), dan $22-120 \times 10^{5} \mathrm{cfu} / \mathrm{ml}$ (eutrofik). Konsentrasi oksigen terlarut (DO) yang didapatkan yaitu berkisar antara $4-8,24 \mathrm{mg} / \mathrm{l}$. Konsentrasi oksigen terlarut jauh dari baku mutu bagi kegiatan perikanan berdasarkan Peraturan Pemerintah Nomor 82 Tahun 2001 kelas III dalam Effendi et al. (2012) yaitu baku mutu DO adalah $3 \mathrm{mg} / \mathrm{l}$. Konsentrasi ini menunjukkan waduk termasuk ke dalam waduk yang produktif (eutrofik) dengan kandungan unsur hara dan bahan organik yang tinggi.

\section{e. Kualitas Perairan}

Kualitas air yang telah diukur dalam penelitian ini mencakup parameter fisika dan kimia. Parameter fisika yang diukur yaitu suhu air dan kecerahan. Parameter kimia yang diukur yaitu derajat keasaman ( $\mathrm{pH})$, oksigen terlarut, dan bahan organik total. Pengukuran parameter ini telah dilakukan pada kedalaman 1 meter.

Suhu air pada sampling pertama di setiap stasiunnya memiliki kisaran yang lebih rendah dibandingkan dengan sampling kedua, yaitu berkisar antara 29 - $30 \mathrm{C}$ pada sampling pertama dan 30 - 30,5 C pada sampling kedua. Hal ini disebabkan pada pada sampling kedua kondisi kejernihan air lebih jernih dibandingkan dengan sampling pertama. Kejernihan air ini berkaitan dengan nilai kecerahan yang didapatkan. Kisaran suhu air yang didapatkan 29 - 30,5 C menunjukkan pada kondisi tersebut mendukung kehidupan bakteri heterotrofik. Menurut Askari (2010) dalam Kristiawan et al. (2014), kondisi suhu air untuk mendukung kehidupan bakteri heterotrofik yaitu berkisar antara $25-37 \mathrm{C}$.

Pengukuran kecerahan didapatkan hasil dengan kisaran $(110-145) \mathrm{cm}$. Kecerahan pada air tersebut masih dalam kategori sedang dan air berwarna hijau jernih. Menurut Effendi (2003), kecerahan air tergantung pada warna dan kekeruhan. Kecerahan merupakan ukuran transparansi perairan, yang ditentukan secara visual dengan menggunakan secchi disk. Nilai kecerahan dinyatakan dalam satuan meter. Nilai ini sangat dipengaruhi oleh keadaan cuaca, waktu pengukuran, kekeruhan, dan padatan tersuspensi, serta ketelitian orang yang meh lakukan pengukuran.

Nilai kecerahan yang didapatkan juga dapat mempengaruhi pertumbuhan bakteri heterotrofik. Pertumbuhan bakteri heterotrofik yang didapatkan yaitu pada sampling pertama menunjukkan rata-rata kelimpahan bakteri heterotrofik lebih tinggi dibandingkan dengan waktu sampling kedua. Menurut Ariadi dan Dewi (2008) dalam Aria et al., (2014), bahwa pertumbuhan bakteri akan sangat dipengaruhi oleh berbagai kondisi yang ada termasuk pengaruh dari lingkungan luar seperti cahaya matahari.

Hasil pengukuran derajat keasaman didapatkan nilai yang tetap yaitu 6, kondisi pH ini sesuai dengan sifat bakteri heterotrofik yang dapat tumbuh dalam lingkungan perairan dalam kondisi $\mathrm{pH}$ netral. Tingkat keasaman yang terlalu tinggi dapat menyebabkan ekosistem perairan dapat terganggu dan kurang produktif. Menurut Jangkura (1984) dalam Yumame et al. (2013), keasaman air mempengaruhi tingkat kesuburan perairan. perairan yang terlalu asam akan kurang produktif. Perairan yang banyak sampah organik terkomposisi dapat ditemukan $\mathrm{pH}$ rendah. Kehidupan biota akuatik semakin terganggu apabila $\mathrm{pH}$ air makin jauh dari titik normal. Menurut Sarief (1993) dalam Kristiawan et al. (2014), dikatakan bahwa pada kisaran pH 6,5 - 7,5 bahan organik tersedia 
dalam jumlah yang cukup banyak (optimal), karena bakteri yang bertindak sebagai dekomposer juga mampu hidup optimal pada kisaran $\mathrm{pH}$ tersebut.

Pengukuran oksigen terlarut pada sampling pertama dan kedua menunjukkan kisaran $(4-8,24) \mathrm{mg} / \mathrm{l}$. Stasiun 1 (outlet) memiliki kandungan oksigen terlarut paling rendah dibanding dengan beberapa stasiun lainnya, dan kelimpahan bakteri heterotrofik sebesar $550 \times 10^{4} \mathrm{cfu} / \mathrm{ml}$ pada sampling pertama dan $700 \times 10^{4} \mathrm{cfu} / \mathrm{ml} \mathrm{pada}$ sampling kedua. Nilai kelimpahan tersebut termasuk ke dalam kondisi populasi yang cukup tinggi diakibatkan adanya pemanfaatan kandungan oksigen terlarut untuk mengoksidasi bahan organik. Menurut Boyd (1988) dalam Effendi (2003), hilangnya oksigen di perairan selain akibat proses respirasi tumbuhan dan hewan juga terjadi karena oksigen dimanfaatkan oleh mikroba untuk mengoksidasi bahan organik.

\section{KESIMPULAN}

Kesimpulan yang diperoleh dari penelitian ini adalah distribusi bakteri heterotrofik di Waduk Jatibarang fluktuasi dan relatif tinggi dengan nilai kelimpahan berkisar antara $\left(450\right.$ - 1310) x $10^{4} \mathrm{cfu} / \mathrm{ml}$. Kandungan bahan organik total yaitu berkisar antara $(11,771$ - 21,883) mg/l. Hubungan kelimpahan bakteri heterotrofik dengan bahan organik total, yaitu hubungan yang terbalik menunjukkan tidak adanya hubungan antara keduanya. Status kesuburan perairan Waduk Jatibarang berdasarkan kandungan bahan organik total $(11,771-21,883) \mathrm{mg} / \mathrm{l}$, kelimpahan bakteri heterotrofik (45 - 131) x $10^{5} \mathrm{cfu} / \mathrm{ml}$, dan konsentrasi oksigen terlarut (DO) $(4-8,24) \mathrm{mg} / \mathrm{l}$, sehingga perairan bersifat eutrofik.

\section{UCAPAN TERIMA KASIH}

Penulis mengucapkan terima kasih kepada Dra. Niniek Widyorini, MS, Dr. Ir. Pujiono Wahyu Purnomo, MS, Prof. Dr. Ir. Djoko Suprapto, D.E.A, Ir. Anhar Solichin, M.Si, dan Dr. Ir. Bambang Sulardiono, M.Si selaku tim penguji serta Churun Ain, S.Pi, M.Si, selaku panitia yang telah memberikan arahan, bimbingan, serta kritik dan saran dalam penyusunan jurnal ini. Serta semua pihak yang telah membantu dan memberikan dukungan.

\section{DAFTAR PUSTAKA}

Aria, G. D., P. Panata, dan R. Leidonald. 2014. Analisis Dampak Kegiatan Wisata terhadap Kualitas Air Sungai Betimus Kecamatan Sibolangit Kabupaten Deli Serdang. Jurnal Aquacoastmarine. Program Studi Manajemen Sumberdaya Perairan. Fakultas Pertanian. Universitas Sumatera Utara. 2(1) : 56 - 65 hal.

Badjoeri, M., dan T. Widiyanto. 2008. Penggunaan Bakteri Nitrifikasi untuk Bioremediasi dan Pengaruhnya terhadap Konsentrasi Amonia dan Nitrit di Tambak Udang. Oseanologi dan Limnologi di Indonesia. Pusat Penelitian Limnologi - LIPI. 34 (2) : 261 - 278 hal.

Badjoeri, M., dan Lukman. 2010. Distribusi dan Kelimpahan Populasi Bakteri Heterotrofik di Danau Toba. Limnotek. 17 (2) : $181-190$.

Badjoeri, M. 2013. Distribusi dan Kelimpahan Bakteri Heterotrofik dan Bakteri Nitrifikasi di Danau Loa Kang Kalimantan Timur. Prosiding Pertemuan Ilmiah Tahunan MLI I. Cibinong. 12 hal.

Effendi, H. 2003. Telaah Kualitas Air bagi Pengelolaan Sumberdaya dan Lingkungan Perairan. Penerbit Kanisius, Yogyakarta. 258 hal.

Effendi, H., E. M. Adiwilaga, dan A. Sinuhaji. 2012. Pengaruh Percampuran Air terhadap Oksigen Terlarut di Sekitar Karamba Jaring Apung Waduk Cirata Purwakarta Jawa Barat. Ecolab. 6 (1) : 1 - 60.

Hayes, J. 2000. Aeromonas hydrophila. MB592-Diseases of fish.

Juantari, G. Y., R. W. Sayekti, dan D. Harisuseno. 2013. Status Trofik dan Daya Tampung Beban Pencemaran Waduk Sutami. Jurnal Teknik Pengairan. 4 (1) : 61 - 66 hal.

Kristiawan, D., N. Widyorini, dan Haeruddin. 2014. Hubungan Bakteri dengan Kandungan Bahan Organik Total di Muara Kali Wiso, Jepara. Diponegoro Journal of Maquares. 3 (4) : 24 - 33 hal.

Marwan, A. H, N. Widyorini, dan M. Nitisupardjo. 2015. Hubungan Total Bakteri dengan Kandungan Bahan Organik Total di Muara Sungai Babon Semarang. Diponegoro Journal of Maquares. 4 (3) : 170 - 179.

Pramono, Z. T., dan A. Subowo. 2015. Akuntabilitas dalam Perencanaan Pembangunan Waduk Jatibarang di Kota Semarang. Jurusan Administrasi Publik. Fakultas Ilmu Sosial dan Ilmu Politik. Universitas Diponegoro. 4 (3) : 14 hal.

Sarwono. 2016. Http://www.jonathansarwono.info/korelasi/korelasi.htm (diakses pada Minggu, 31 Juli 2016, pukul 17.00 WIB).

Standar Nasional Indonesia 06-6989.22-2004 : Air dan Air Limbah-Bagian 22: Cara Uji Nilai Permanganat Secara Titrimetri. Badan Standarisasi Nasional. Jakarta.

Yumame, R. Y., Robert, Rompas, dan N. P. L. Pangemanan. 2013. Kelayakan Kualitas Air Kolam di Lokasi Pariwisata Embung Klamalu Kabupaten Sorong Provinsi Papua Barat. Budidaya Perairan. 1 (3) : 56 62 hal. 